\title{
Identification of Cellular Phone for Elderly Users: A Literature Review
}

\author{
Anita Juraida*, Annisa Maharani Sunyoto, Ima Ratnasari, Nurlaela Nisfiani \\ Department of Industrial Engineering, Faculty of Engineering, Widyatama University, Indonesia
}

Copyright $\mathrm{C} 2019$ by authors, all rights reserved. Authors agree that this article remains permanently open access under the terms of the Creative Commons Attribution License 4.0 International License

\begin{abstract}
Purpose: to identify the need of cellular phones for elderly users. Design/methodology/approach: Methodology is done through literature reviews from the relevant literature. Findings: The results of the study are that the elderly people have obstacles experience to the use of technology because physical and cognitive decline and lack of experience in using technology. Research limitations/implications: This study only identified the elderly as a whole, whereas the elderly had three types, namely the elderly group (55-65 years), the elderly group (65 years and over), and the high-risk elderly group which namely the elderly over 70 years of age. Practical implications: Research results can be input for cellular phone designers to make user friendly cellular phone. Originality/value: This research has added value to developing cellphone phones that are easy to use for the elderly
\end{abstract}

Keywords Cellular Phone, Communication, Elderly, Product Development, Technology

\section{Introduction}

In developed countries, the aging population has been anticipated since the beginning of the 20th century, so that people in developed countries are better prepared to face aging with all the challenges, but now developing countries face the same problem. This phenomenon brings a number of consequences, including the emergence of physical, mental, social, and health care (Clark, 2002).

One of the antipasies of elderly to face challenges is to provide self-reliance facilities, one of which provides mobile phones. Today, cellular phones have become an important tool for everyday life. People around the world use cellular phones Cellular telephones are electronic telecommunication devices that have the same basic capabilities as conventional fixed lines, but can be carried anywhere (portable mobile) and do not need to be connected to telephone networks that use cable.

Cellular telephones experience development in various aspects of function, not only a device to call contacts, but also a cellular phone generally has a means to enter personal phone directories, alarm clocks, reminders, and some types of games (Klockar, et al, 2003). The development of these technologies broadens the use of dimensions of cellular phones and creates social and functional benefits.

The existence of these developments received appreciation from the world community and Indonesia. According to a report from the International Telecommunications Union (ITU), mobile phone users around the world are expected to increase to 6.835 billion or $98 \%$ of the total population in 2013 . This proves that almost all people in the world have cellular phones. This information can be seen more fully in Figure 1.

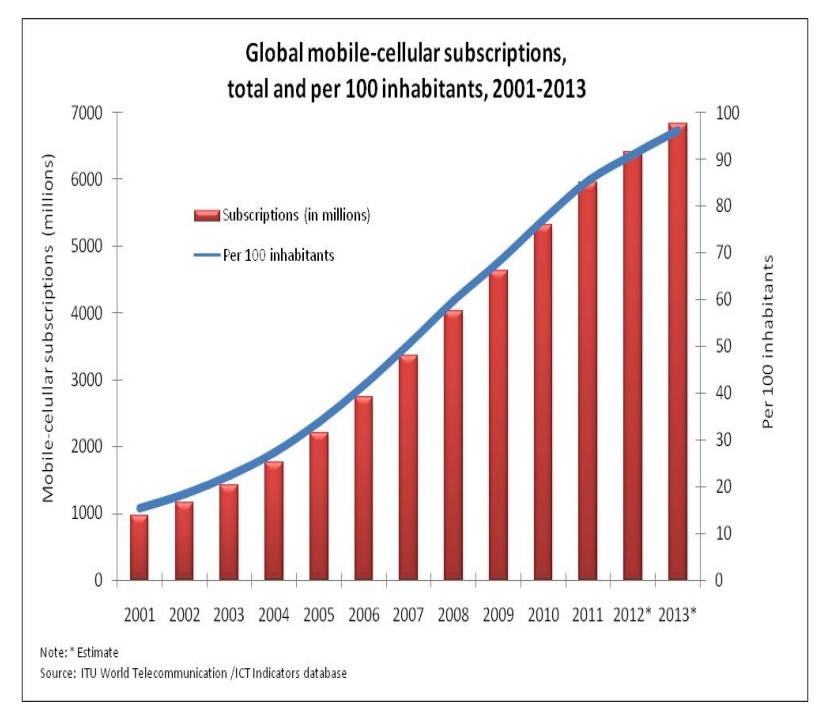

Source: http://www.itu.int

Figure 1. Cellular Phone Users in the World

The use of cellular phones is used by all ages, including the elderly category. A Linkage Research Institute (2012) shows that the elderly use technology tools, and the 
greatest level of ownership in the technology category is by using cellular phones. This information can be seen in Figure 2.

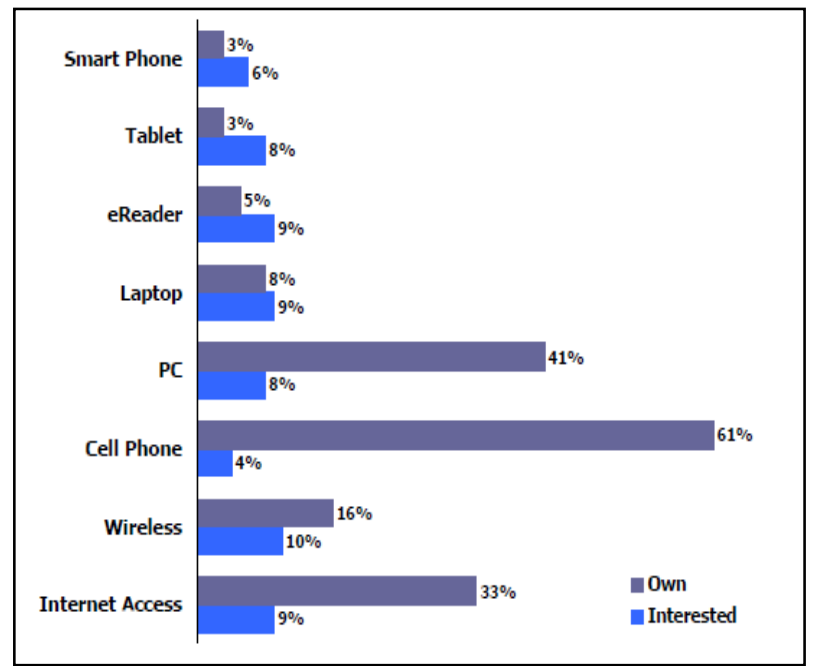

Source: http://www.Linkage

Figure 2. Use of Technology Devices by the Elderly

This statement is also supported by other studies. According to SUS-IT (2010), an institution that pays attention to the elderly (elderly), has surveyed the use of technology in the elderly in everyday life. The survey results showed that of 750 elderly people over 50 years of age surveyed, almost all elderly people used at least one electronic device, with about one third of the elderly using between 2-5 devices, and two thirds using 6-10 different devices. The most commonly used electronic devices are cellular phones (used by almost $90 \%$ of respondents).

Today, cellular phone design has evolved with the thinking of young users, but access to cellular phone technology can offer elderly users the opportunity to maintain their quality of life. One common social problem experienced by the elderly is loneliness. Elderly are at high risk of experiencing loneliness because their chances of being in the midst of many people are often rare. Decreasing sensory abilities that make communication difficult and cause frustration, or isolation from institutional centers (hospitals or nursing homes) can limit opportunities for the elderly to meet other people (Rahmawati, 2012).

The existence of these cellular phone products is beneficial for the elderly so they are not lonely, and has the potential to make the lives of the elderly easier, support communication with family and friends, help health care, and help the elderly stay safe and functional and independent in everyday life (Dickinson \& Hill, 2007). Cellular phones build the possibility of the elderly to communicate from anywhere and at any time, without the need to be connected to fixed phones, thus opening up new possibilities for communicating privately, and getting various information and work.

\section{Literature Review}

\subsection{Definition of Elderly (Elderly)}

According to the Republic of Indonesia Law Number 13 of 1998 Article 1 Paragraph 2 concerning Elderly Welfare, stipulates that "Elderly" is someone who has reached the age of 60 (sixty) and above. The classification of the elderly according to the Ministry of Health (2000), into three groups, namely the elderly elderly group (55-65 years), the elderly group (65 years and over), and the high-risk elderly group, namely the elderly over 70 years of age. According to the World Health Organization (WHO), although there is a general definition of aging, there is no general agreement regarding the age at which a person becomes old. Common usage of calendar age to see the threshold of old age which is usually equated with biological age, but at the same time, in general they are not always identical.

\subsection{Cellular Phones}

Mobile Phones are electronic telecommunications devices that have the same basic capabilities as conventional fixed lines, but can be portable (portable). In addition to functioning to make and receive phone calls, cellular phones generally have the function of sending and receiving short messages (short message service, SMS). There are also cellular phone service providers in several countries that provide third generation $(3 \mathrm{G})$ services by adding videophone services, as a means of payment, as well as for online television in cellular phones. At present, cellular phones have multifunctional features equipped with a variety of features, such as capture radio and television broadcasts, audio player software (MP3), videos, cameras, digital games, and internet services (WAP, GPRS, $3 G)$.

\section{Method}

Data is done through literature reviews from the relevant literature. The results of this data were then analyzed to find out the description of the limitations and needs of the elderly regarding cellular phones.

\section{Findings}

\subsection{Elderly Limitations in Using Cell Phones}

The benefits felt by the elderly regarding the use of cellular phones do not synergize with the design of cellular phone products that are currently in place. This comes from the fact that most cellular phone products have many functions, and operations are often perceived 
as complicated, so that the technology is beyond the limits of the ability of the elderly.

The limitations experienced by the elderly are caused by two obstacles that avoid the use of cellular phones (Zhao, 2001). First, most elderly people today have spent most of their lives without the current computing technology, so they usually have limited experience with technology. Second, the elderly face barriers to the use of technology because they experience physical and cognitive decline. This experienced decline varies in each elderly, but generally this decrease is related to vision, hearing, psychomotor skills, and decreased memory with age. The elderly showed a significant reduction in the visual field, light sensitivity, color perception, resistance to glare, dynamic and static acuity, contrast sensitivity, visual search and processing, and pattern recognition. Their reasoning ability also decreases. The power of spatial memory memory and working memory shows a decrease, which has a significant effect on learning difficulties (Rachmawati. 2012; Zhao, 2001).

\subsection{Elderly Complaints in Using Cell Phones}

Aging is always accompanied by changes in all systems in the human body. Changes in all systems in the human body are for example in the nervous system. These changes can lead to a decrease in the work function of the brain. Based on the results of literature review, most complaints of cell phone use are related to screens that are too small and difficult to see, buttons and characters that are too small cause them to often call the wrong number, they also avoid using complex features, as well as menu settings not user-friendly. This is reinforced by the study of Samsunuwiyati (2012), at the age between 40 and 59 years, the accommodation power of the eye experienced the sharpest decline and hearing is the two most prominent physical changes, consequently many middle-aged people have difficulty seeing objects so close.

These limitations make the elderly feel the digital divide, where many products are made only for the benefit of the general age, these differences make the elderly unable to use technology products. The elderly seem to be a group of users who are ignored in the design of cellular phones, even though the elderly population at this time is increasing.

\section{Discussion and Conclusions}

There are a high number of elderly people and basically the needs felt by the elderly in the use of cellular phones. This is a market potential that has not been properly considered. According to the International Organization for Standardization, uniform product design and service standards for the elderly are now important to society, because accessibility issues have become more serious with the increasing number of elderly people around the world. The standard design of products and services has a significant influence on the interests of customers.

\section{REFERENCES}

[1] Clark, J. (2002). Older Adults Living Through and With Their Computers, Retrieved from http://www.nursingcente r.com/lnc/JournalArticle?Article_ID=274944

[2] Dickinson, A. and Robin, L. (2007). Keeping In Touch: Talking to Older People about Computers and Communication, Journal Educational Gerontology, 33, 8.

[3] Global Mobile Phone Users. (n.d). Older Adults Living Through and With Their Computers, Retrieved from https://www.itu.int/search\#?q=indonesia\&fl=0\&ex=false

[4] ISO. (2007). ISO/IEC publishes survey of icons and symbols to benefit IT users, including the disabled and elderly, Retrieved fromhttps://www.iso.org/news/2007/07/ Ref1065.html

[5] Kementrian Kesehatan. (2017). Tetap Sehat di Lanjut Usia, Retrieved from http://www.depkes.go.id/article/view/1705 3000004/tetap-sehat-di-usia-lanjut.html

[6] Klocker, T. (2013). Usability of mobile phones, Proceedings of the 19th Internasional Symposium on Human Factors in Telecommunications, Gemany.

[7] Linkage. (2012). Technology Survey Age 65 to 100 Extending Technology Past the Boomers, Retrieved from http://www.linkageconnect.com/files/1/Articles/Technolog ySurveyFinalCopyFeb2012.pdf

[8] Rahmawati. (2012). Mengenalkan Internet Kepada Lansia, Retrieved from http://lifestyle.kompasiana.com/catatan/20 12/11/02/mengenalkan-internet-kepada-lansia-505452.htm

[9] Samsunuwijayati, M. and Lieke, I. (2012). Perilaku Manusia. Jakarta: Refika Aditama.

[10] SUS-IT. (n.d). Older people and digital engagement, Retrieved from http://sus-it.lboro.ac.uk/SusIT_Briefing_Pa per_1.pdf

[11] Treeratanapon, T. (2012). Design of the Usability Measurement Framework for Mobile Applications., In International Conference on Computer and Information Technology (ICCIT'2012), Thailand.

[12] Undang-undang Republik Indonesia. (1998). Undang-undang Republik Indonesia Nomor 13 Tahun 1998, Retrieved from www.bpkp.go.id/uu/filedownload/2/ 45/438.bpkp

[13] World Health Organization (WHO). (2018). Ageing and Health, Retrieved from http://www.who.int/news-room/fac t-sheets/detail/ageing-and-health

[14] Zhao, H. (2001). Universal Usability Web Design Guidelines for the Elderly (Age 65 and Older), Retrieved from www.otal.umd.edu/uupractice/elderly 